\title{
Information Technology and Transcription of Reading Materials for the Visually Impaired Persons in Nigeria
}

\author{
Christopher Nkiko ${ }^{1}$, Morayo I. Atinmo ${ }^{2}$, Happiness Chijioke Michael-Onuoha ${ }^{1}$, Julie E. Ilogho ${ }^{1}$, Michael O. \\ Fagbohun ${ }^{1}$, Osinulu Ifeakachuku ${ }^{1}$, Basiru Adetomiwa ${ }^{3} \&$ Kazeem Omeiza Usman ${ }^{4,5}$ \\ ${ }^{1}$ Covenant University, Ota, Ogun State Nigeria \\ ${ }^{2}$ Department of Library, Archival and Information Studies, University of Ibadan, Ibadan, Nigeria \\ ${ }^{3}$ Redeemer's University, Ede, Osun State, Nigeria \\ ${ }^{4}$ Digital Library Learning, Tallinn University, Tallinn, Estonia \\ ${ }^{5}$ University of Parma, Parma, Italy
}

Correspondence: Christopher Nkiko, Covenant University, Ota, Ogun State Nigeria. E-mail: christopher.nkiko@covenantuniversity.edu.ng

Received: August 5, 2017

Accepted: August 14, $2017 \quad$ Online Published: September 6, 2017

doi:10.5539/jel.v7n1p42

URL: https://doi.org/10.5539/jel.v7n1p42

\begin{abstract}
Studies have shown inadequate reading materials for the visually impaired in Nigeria. Information technology has greatly advanced the provision of information to the visually impaired in other industrialized climes. This study investigated the extent of application of information technology to the transcription of reading materials for the visually impaired in Nigeria. The study adopted survey research design of the ex-post facto to select 470 personnel as respondents. A questionnaire titled Information Technology Use Scale $(\alpha=0.74)$, and Interview Schedule $(\alpha=0.75)$, were used. Data were analyzed using descriptive statistics and Pearson Product Moment Correlation. The findings indicate that information technology in transcription was low and a significant positive relationship between application of information technology and transcription of information materials $(\mathrm{r}=0.62$ : $\mathrm{p}<0.05)$. The study recommended among others that Multi-National Corporations should be sensitized to extend their Corporate Social Responsibility (CSR) activities to help in procuring modern information technology devices and software to enhance transcription.
\end{abstract}

Keywords: information technology, visually impaired, reading materials, transcription, alternative formats

\section{Introduction}

Transcription involves the act of adapting or converting text, sound, graphics and electronic files into accessible format for the visually impaired. Transcription service is focused on delivering inclusive dissemination of information through high quality alternative formats. The most common alternative formats include: Braille, Audio cassette and Compact Disc, Large print, Electronic files. These ensure that the recipients access preferred format with the same content and quality as the original document. Cotis (2001) observed that transcription to alternative formats has expanded in scope and content particularly as a result of the 2005 Disability Discrimination Act (DDA).

Information Technology (IT) is a broad subject which deals with the use of electronic computers and relevant software to convert, store, protect, process, transmit and retrieve information (Rendulic, 2011). Over the past twenty years, its prevalence has dramatically increased such that it is now a part of nearly every aspect of daily life. Information technology as a social system is recognised worldwide as a tool that accelerates economic and social integration. It is used as a medium for collaborative learning and for overcoming barriers to learning and performance (Gusen, 1998). Computers with synthetic speech (Duxbury word processor) can help in pronouncing texts for a blind person. The computer can tell the blind user other descriptive information that is displayed on the screen. Computer Braille printer can print text for the blind in Braille and vice versa. Some computer Braille printers can print in regular text between the lines of Braille. Teachers can also use the computer to type in standard orthography and have assignments and other documents transcribed in Braille for those who require it (Hill, 1990; Apple, 1992; Gusen, 1998; Banes, 2009). 
Information technology has overwhelming influence on efficient and sustainable production of any sort. Industrialised nations have used technology tremendously to enhance the quality of life of the persons with impairment generally and the visually impaired in particular. Atinmo (2000) reported that technology has advanced so much in the area of library and information services that there are now a variety of computer based devices that translate printed materials into raised letter, synthesised speech or enlarged formats for the visually impaired.

The above assertion was corroborated by Gallimore (1999), who noted that access to technologies has greatly assisted the provision of information in recent years. According to him, the most radical change came with the widespread use of computers, whereby the visually impaired could easily convert print into electronic text and read it from the screen with either transitory Braille or through synthetic speech. He further observed that it is also possible to link different converters such as scanners, reading machines, embossers and tape recorders, so that a converted text can be permanently recorded in the desired format. The internet has made it possible for the visually impaired to access information at the same time as sighted users, and has dramatically improved equality of access, bringing independence and choice - two of the fundamentals of freedom (Porter, 1997).

With adaptive software students with visually impairment can access the web and other popular applications via synthetic speech, magnified images, and/or Braille displays. Often, this involves using a standard QWERTY keyboard, but sometimes students may also use a mouse, touch screen, or dictation software. As part of IT tool for transcription of reading materials into alternative format for the visually impaired is screen reading software. Screen-reading software uses synthetic speech to read aloud the content that appears on a computer screen. Screen-readers can help users access many word-processing programmes, spreadsheets, presentation applications, and internet browsers, often with key strokes rather than moving by a mouse. There are screen readers available for PCs running Linux or Windows operating systems. Each type of screen-reading software uses a different command structure and most support a variety of speech synthesizers.

Some students with low vision may benefit simply from using a large computer monitor or from adjusting the appearance settings on their computer, such as font size, screen resolution, scroll bar size, icon size, colour scheme, and mouse cursor appearance (Windows also has a screen magnifier as part of its accessibility features). Many students with low vision, however, may find screen magnification software to be a more viable option. Full-featured screen magnifying programmes work similarly to a high-powered magnifying glass moving over a page. They can magnify all screen items by following the mouse cursor, or they can move across and down a page at a preset speed. Students who are blind or have low vision usually learn to touch-type on QWERTY keyboards. If a blind student has an additional physical disability that affects his/her typing proficiency, the student may be interested in trying dictation software. Even the traditional tools like stylus and Braille are combined with IT tools.

Students may choose to handwrite Braille using a Slate and stylus or type Braille directly with a Perkins braillewriter. Transcribers also find it useful to convert electronic text into a Braille hard copy by sending computer files to a Braille embosser, which is the Braille equivalent to an ink printer.

There exists now a technology called Braille 2000. It is a bold new tool for producing Braille. Braille 2000 is said to be fully internet compatible, making it as simple as a mouse click to send a document to a Braille production centre, to a school, to a blind student or a fellow transcriber. Braille 2000 is fully compatible with ED-IT PC and is able to read and write Braille XML files as well as translate XML print text into Braille.

The application of information technology devices and tools such as computers, braille embossers, dolphin pen, jaws, Duxbury braille translators, converters, synthetic speech software etc. are vital for modern transcription. Contrary to this, Gusen, Amv, and Milaham (2010) observed that the commonest tools for transcription in Nigeria are perkins braille, slate, stylus, tape recorders, talking calculators and embossers. The position was further confirmed by Atinmo (2005) who posited that Braille production is mostly manual — driven as only 12 out of 75 institutions surveyed use computer Braille facilities. However, Lang and Upah (2008), Fuandai (2010) Omede (2011) and Babalola and Haliso (2011) argued that transcription in Nigeria is mostly inhibited by insufficient funding, unskilled manpower, inadequate assistive technology, policy deficiencies, high cost of production and over reliance on foreign donation. In Nigeria, it is estimated that the population of the visually impaired is between two to three million (that is, about 1.2 to $1.8 \%$ of the entire population of approximately 170 million people) (Tiamiu, 2003). Despite this large number, the production and distribution of transcribed reading materials for this group are quite low. It is important to note that Non-governmental organisations are chiefly responsible for the provision of textbooks, religious and few other general reading materials in alternative formats. Some visually impaired students are frustrated out of school due to lack of access to reading materials. In some cases, these visually impaired students have to make individual efforts to find their own reading materials. Opportunities to 
read for informal learning, personal development, recreation and entertainment are virtually non-existent. These observations have directed attention to the tendency for the educated visually impaired to relapse into secondary illiteracy. They also become alienated and impoverished for lack of sufficient provision of reading materials in the appropriate formats accessible to them.

The transcription activities in Nigeria revolves around the secondary schools, tertiary institutions, libraries that cater for the visually impaired as well as the NGOs that specialize in transcription for this group of users. They would therefore form the population for the study.

The intensive application of information technology in the transcription of reading materials for visually impaired becomes imperative if appreciable progress must be made. It is against this background that the study investigated the extent of application of information technology in transcription of reading materials for the visually impaired in Nigeria.

\section{Research Question}

A research question was raised to wit:

What is the extent of Information Technology (IT) application in the transcription of reading materials into alternative formats for the visually impaired in Nigeria?

\section{Hypothesis}

The study tested a null hypothesis at 0.05 significant level thus:

There will be no significant relationship between information technology and transcription of reading materials into alternative format for the visually impaired in Nigeria.

\section{Literature Review}

Information Technology has revolutionalized and expanded both accessibility and availability of various formats into which reading materials for the visually impaired could be transcribed. Evans (2000) described access to technologies such as the Kurzweil Reading Machine and Closed Circuit Television (CCTV) as having greatly assisted in the provision of information to the visually impaired in recent times. The most radical innovation came with the widespread use of computers where visually impaired people could easily convert print into electronic text and read it from the screen with either transitory Braille or through synthetic speech. It is also possible to link different converters such as scanners, reading machines, embossers and tape recorders, so that a converter text can be permanently recorded in the desired format (Long, 1993; Gallimore, 1999).

Pollitt (2003) reported the designing of a web interface which offers the best opportunity to make the catalogue of libraries accessible to people with print disabilities. Visually impaired users may change the appearance of the web page using accessibility options of their browser software or use screen enlargements software to control the magnification of the web page. Screen readers' software can then be used to interpret the coding of the web page and interact with the browser to output the content as synthetic speech or to a refreshable Braille display (Craven, 2000).

Horten and Horten (1995) have observed that Braille books were traditionally produced by typing the printed book in Braille on a Perkins Brailler but that this has changed in the last decades. They noted that at first, the books were typed on a personal computer and the text transformed to Braille by Braille conversion software. Another stage was that printed books were scanned on a scanner with an optical character recognition programme, which photographed and translated the printed letters into text. The text was then transformed to Braille by the Braille conversion software. They also asserted that in Norway, a new option known as "Data Technology" is used by authors, publishers and printing houses to retrieve text directly as a basis for the transcription into Braille and talking books. This provides a platform to give the visually impaired more books to read by making the transcription of Braille books more efficient as well as permit the production in varied formats like CD-ROMs.

Kuniansky (2001) stated that an Electronic-Braille system now exists that allows a librarian using a web-based mechanism to go to a website where he can quickly and easily transcribe an information requested by blind person into Braille, before delivering the electronic Braille to visually impaired users with a refreshable Braille display of their own Braille embosser. With E-Braille, documents could be received, transcribed to Braille, embossed and shipped. An initiative to enable visually impaired persons in Vietnam to have access to newspaper and magazines was established in 2001. According to Nguyen (2005), visually impaired persons can dial into a central location where natural voice recordings are stored in a computer. These are accessed by the reader using the keypad of the touch phone or by calling different phone numbers for different sections of the newspaper or magazine which are then converted into Braille format. With this method, it is possible for a whole recorded newspaper to be made 
available in Braille and users can select particular sections of each newspaper either by using different phone numbers or with their phone keypads using numerical codes (Vappu \& Leanor, 1995). Telephone accessible systems for Braille materials are available in a number of countries including Australia, Canada and the United States of America (Craddock, 1996).

Verhoeven (2005) reported the existence of a portable USB pen device known as "Dolphin Pen" used for transcription to alternative formats. Dolphin Pen has a complete range of capabilities to allow the conversion of all text-based reading materials into large print, audio MP3, Braille or DAISY digital talking book formats. Through dolphin pen, the visually impaired are able to access internet or web-based resources. Academic libraries and Internet cybercafés can deploy this device to their computers and thus provide automatic transcription mechanisms for the visually impaired. This ensures equity of access to information. It also offers total freedom and independence to blind and low vision computer users.

\section{Methodology}

All the identified respondents were involved in the study. Total enumeration technique called census was used to capture a population of 513 respondents out of which 470 respondents responded to the survey. This comprised the heads of institutions, all staff directly involved in the transcription and other personnel whose daily activities influence the nature and processes of transcription into alternative format. Out of the 513 copies of questionnaire distributed/administered, 470 were retrieved and found usable and this represents the response rate of the study. The response rate achieved constitutes $91.6 \%$ of the total estimated population of the study. The null hypothesis was tested at 0.05 level of significance using Pearson Product Moment Correction while the research question was subjected to descriptive statistics. An interview schedule was also used to elicit information from respondent organizations. Nine interviews were conducted. One interview was conducted in each of the following organisations:
1) Gindiri Material Centre for the Blind (Plateau State).
2) Anglo-Nigerian Welfare Association for the Blind Library, Lagos.
3) Inlak Library for the Visually Handicapped, Lagos.
4) Ikeja farm Craft Centre for the Blind, Lagos.
5) Niger Wives Braille Production Centre, Lagos.
6) Pacelli School for the Blind, Lagos.
7) Orji River Rehabilitation Centre for the Blind, Enugu.
8) Bola Ige Information Technology Centre, Abuja, (Braille Unit).
9) Hope for the Blind, Zaria.

The target audience for the interview were Head of NGO's. These are organisations that are directly involved with the transcription of reading materials into alternative formats for the visually impaired people.

\section{Results and Findings}

Research question: What is the extent of information technology application in the transcription of reading materials into alternative format for the visually impaired in Nigeria?

Table 1. IT tools applied for the transcription of reading materials

\begin{tabular}{llllll}
\hline $\mathrm{S} / \mathrm{N}$ & Information Technology Facilities & $\mathrm{N}$ & $\%$ & $\mathrm{Mean}$ & Standard Deviation \\
\hline 1 & Embossers & 279 & 59.3 & 4.0 & 1.4 \\
2 & Tape Recorders & 274 & 58.2 & 4.0 & 1.6 \\
3 & Talking Calculators & 137 & 29.2 & 3.1 & 1.2 \\
4 & Scanners & 136 & 28.8 & 3.0 & 1.6 \\
5 & Computer with Brailling Software (Duxbury) & 108 & 22.9 & 2.9 & 1.1 \\
6 & Handheld Magnifier & 94 & 20.0 & 2.5 & 0.9 \\
7 & Jaws Computer & 88 & 18.6 & 2.4 & 1.1 \\
8 & Dolphin Pen & 63 & 13.2 & 2.4 & 1.6 \\
\hline
\end{tabular}




\begin{tabular}{llllll}
\hline 8 & Electronic Braille System & 54 & 11.4 & 2.3 & \multicolumn{1}{l}{1.3} \\
9 & Optical Character Recognition System & 43 & 9.2 & 2.3 & 1.2 \\
10 & Synthetic Speech Software & 43 & 9.2 & 2.2 & 0.8 \\
11 & Kurwzeil Reading Machine & 40 & 8.5 & 2.2 & 0.8 \\
12 & Data Technology & 35 & 7.4 & 2.0 & 0.9 \\
13 & Braille 2000 & 35 & 7.4 & 2.0 & 0.9 \\
14 & Closed Circuit Television (CCTV)) & 28 & 6.0 & 2.0 & 0.7 \\
16 & Converters & 25 & 5.4 & 2.0 & 0.7 \\
\hline
\end{tabular}

Table 1 showed that the most commonly applied IT tool by transcribers is Embossers with $59.3 \%(\overline{\mathbf{X}}=4.0$, $\mathrm{SD}=1.4)$ while core IT tools like Duxbury is $22.9 \%(\mathrm{x}=2.9, \mathrm{SD}=1.1)$, Jaws Computer $18.6 \%(\overline{\mathbf{X}}=2.4, \mathrm{SD}=1.1)$, and Braille 2000 is $7.4 \%$ ( $\overline{\mathbf{X}}=2.0, \mathrm{SD}=0.9)$. The trend as seen from the table is that the more sophisticated the IT device, the lower the percentage of use. This means that the application of information technology to transcription in Nigeria is low.

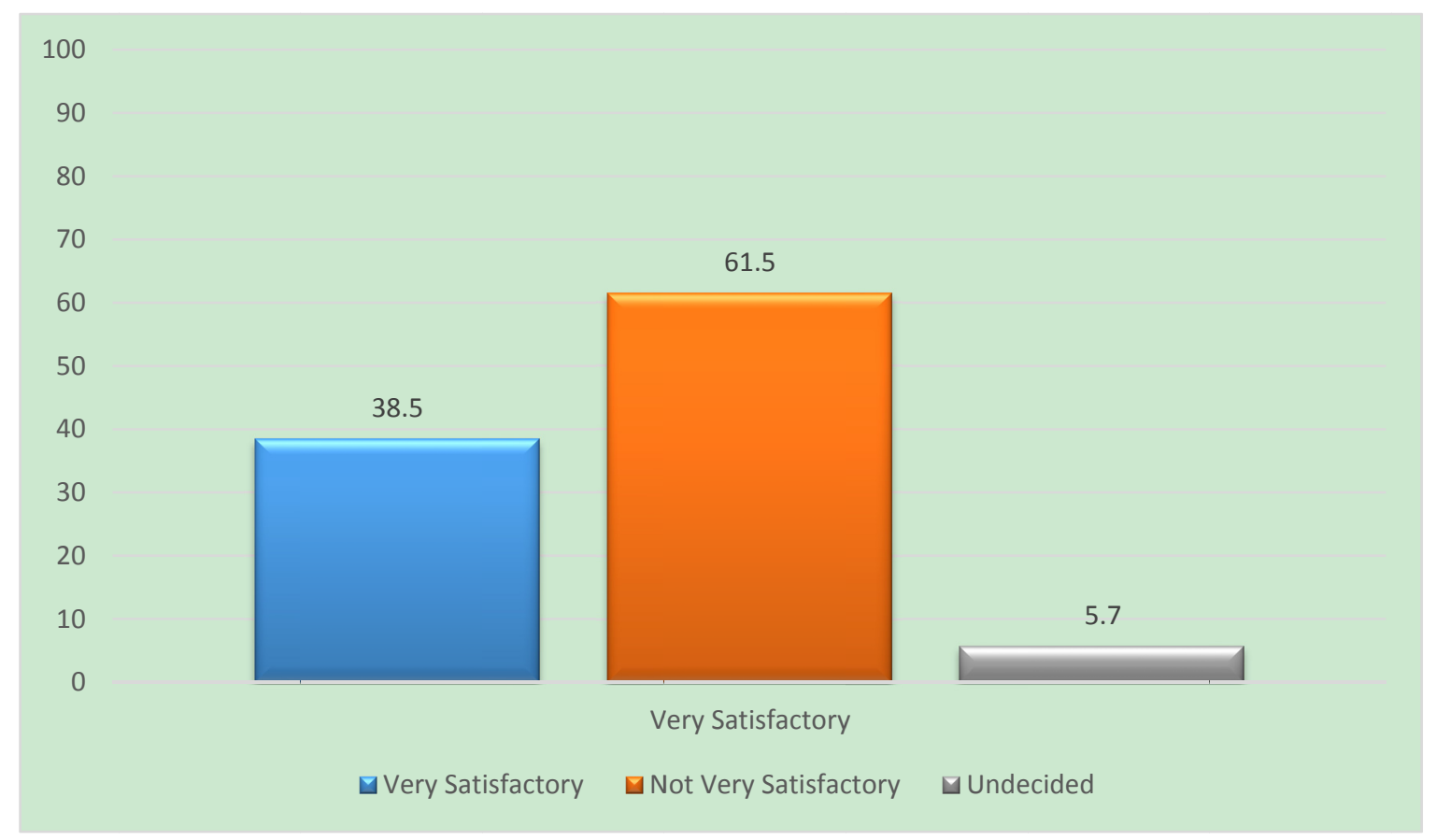

Figure 1. Degree of respondent's satisfaction with existing ICT transcription facilities

Figure 1 indicates that the majority (61.5\%) of the respondents are not satisfied with the application of ICT in the transcription of reading materials for the visually impaired while about $38.5 \%$ of the respondents were satisfied with ICT applications. The poor satisfaction level of respondents may not be unconnected with the high cost of the ICT facilities which makes it too expensive for them to afford. 


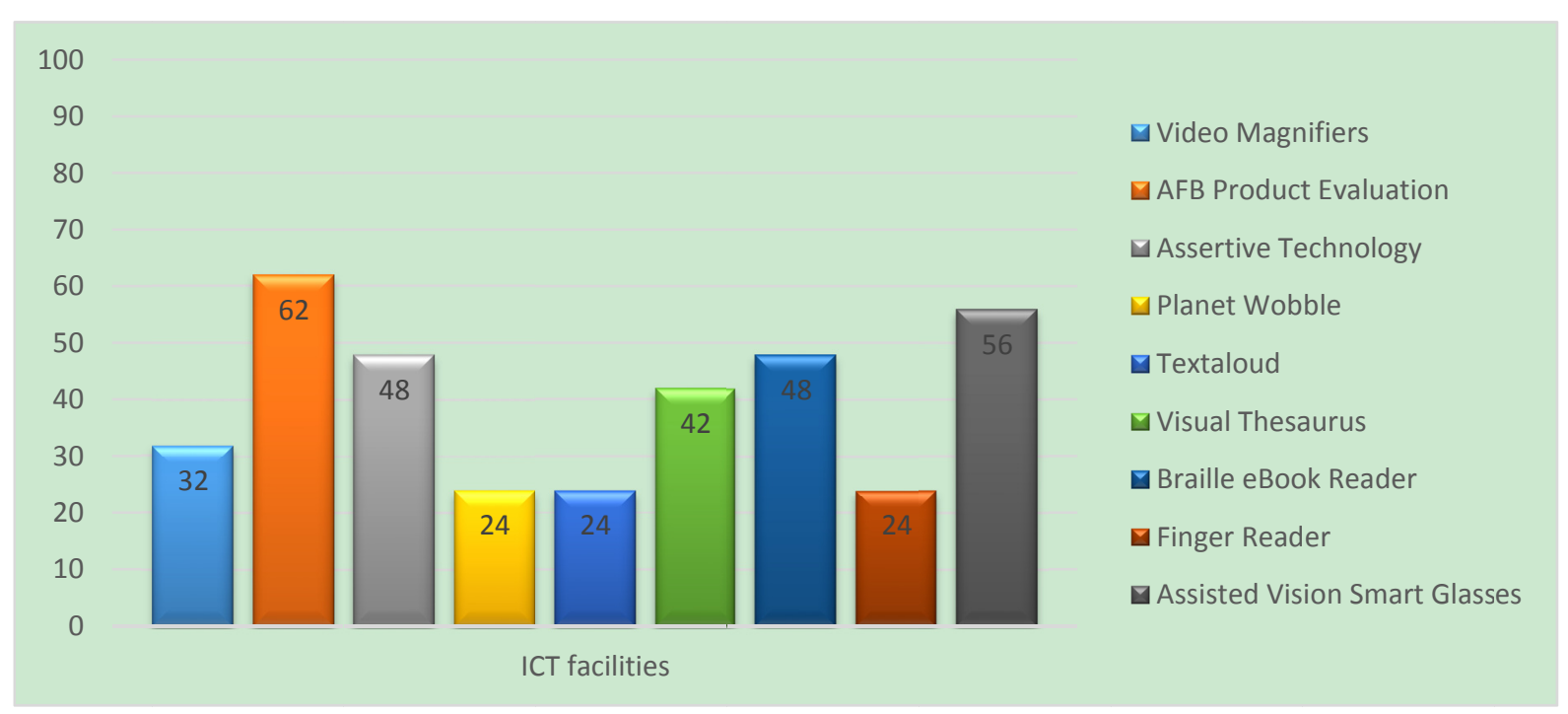

Figure 2. ICT facilities that participants would like to have available for use in TAF

The participants identified nine ICT facilities with AFB Product Evaluation as the highest representing $62 \%$. This goes to underscore the fact that majority of the respondents are aware of current global trends in the area of development of technologies for enhanced productivity in meeting the information transcription needs of the visually impaired. The high level of expectation is not matched with the actual availability of technologies hence the low satisfaction as evidenced in Figure 1.

INTERVIEW RESULT: 1) Which ICT facilities used for transcription are you aware of?

Table 2. ICT in the transcription of reading materials

\begin{tabular}{|c|c|c|c|c|c|c|c|c|}
\hline Gindiri Material & Anglo- Nigerian & Inlak Library for the & Ikeja Farm Craft & Niger-Wives Braille & Pacelli School for & Orji River & Bola Ige Information & Hope for the Blind \\
\hline Centre for the & Welfare Association & Visually Handicapped & Centre for the & Production Centre & the Blind & Rehabilitation & Centre & \\
\hline Blind & for the Blind Library & & Blind & & & Centre for the Blind & & \\
\hline "There are so & "Kurwzeil Reading & "There are a wide range of & "Yes technology is & "Quite a lot, Braille & "Duxbury, & "I am aware of & "The use of ICT In & "The practice is \\
\hline many ranging & Machine, Embossers, & technologies for & affecting the Brailing & 2000, Synthetic & Scanners, Jaws, & Brailing Computers, & transcription is the in- & beyond Perkins and \\
\hline from Jaws & Dolphin, Talking & transcription especially in & system now. & Speech Software, & Internet, Handheld & Embossers, Dolphin, & thing. Some of them & Stylus now. \\
\hline Computer, & Calculator" & the Western World. I can & Computers are used, & Jaws Computer, & Magnifiers, & OCR Kurwzeil, & include Duxbury, & Computers and \\
\hline Scanners, & & talk of Computer for & Embossers, & Duxbury, Kurwzeil & Kurwzeil and & Synthetic Speech & Jaws, Embossers, & Internet Facilities \\
\hline Duxbury, & & Brailing, Scanner & Scanners, & Reading Machine, & Computers" & Software and & Dolphin, OCR, & are now involved in \\
\hline \multirow[t]{3}{*}{ Embossers etc." } & & Duxbury, Embossers, & Converters". & Embossers, Talking & & Computers" & Kurwzeil and & transcription" \\
\hline & & Dolphin Pen, Tape & & Calculators, A host of & & & Computers" & \\
\hline & & Recorder" & & others" & & & & \\
\hline
\end{tabular}

Source: Nkiko (2013). Copyright Exemption and Information Technology as Factors Influencing Transcription of Reading Materials into Alternative Format for the Visually Impaired in Nigeria, Unpublished Ph.D Thesis, University of Ibadan.

Table 2 depicts the respondent institutions awareness of ICT facilities used for transcription. A cross-section of responses showed a wide spectrum of such facilities like Jaws Computer, Scanners, Duxbury, Embossers, Kurwzeil, Dolphin Pen, Talking Calculator, Converters, Synthetic Speech Software. It is a further corroboration of the awareness level of the respondents as regard the existence of multifaceted devices and tools for modern transcription.

INTERVIEW RESULT: 2) Which IT facilities do you have available for transcription? 
Table 3. ICT in the transcription of reading materials

\begin{tabular}{|c|c|c|c|c|c|c|c|c|}
\hline Gindiri Material & Anglo- Nigerian & Inlak Library for the & Ikeja Farm Craft & Niger-Wives Braille & Pacelli School for & Orji River & Bola Ige & Hope for \\
\hline Centre for the & Welfare Association & Visually & Centre for the & Production Centre & the Blind & Rehabilitation & Informatio & the Blind \\
\hline \multirow[t]{2}{*}{ Blind } & for the Blind Library & Handicapped & Blind & & & Centre for the & n Centre & \\
\hline & & & & & & Blind & & \\
\hline "We have & "Our centre is very & "We have functional & "We have a Braille & 'We train transcribers & "When it comes to & "We use mainly & Embossers, & 'We have \\
\hline Embossers, Tape & active in transcription & Embossers, Scanners & Centre here in & and transcribe for various & mass transcription & Perkins Brailing & Scanners & computer, \\
\hline Recorders, & and even we help other & Kurwzeil, Handheld & Lagos that & schools and libraries. We & we outscore to & Machine, Slate & and & Scanners \\
\hline Scanners but most & institutions to & Mangnifiers, & transcribes using & have Duxbury, Jaws, & other IT equipped & and Stylus". & Computers & and \\
\hline times we use & transcribe. We use & Winbraille, Duxbury, & Perkins, Embossers & Embossers, Scanners, & centers but we & & & Embossers". \\
\hline Perkins and & Embossers, Duxbury, & Jaws, Tape Recorders & and some & Kurwzeil, Windbraille, & have Perkins and & & & \\
\hline \multirow[t]{4}{*}{ Stylus". } & Jaws, Scanners, & Computers, & computers. We & Scanners, Internet & Stylus". & & & \\
\hline & Kurwzeil, Computer, & & send our materials & Facilities and other IT & & & & \\
\hline & Talking Calculators, & & there to be & tools". & & & & \\
\hline & Winbraille etc." & & transcribed for us" & & & & & \\
\hline
\end{tabular}

Source: Nkiko (2013). Copyright Exemption and Information Technology as Factors Influencing Transcription of Reading Materials into Alternative Format for the Visually Impaired in Nigeria, Unpublished Ph.D Thesis, University of Ibadan.

Table 3: Beyond awareness of the existence of technologies for transcription, the interview investigated the actual informative facilities available within the institutions for transcription. The responses indicated that the average facilities available include Embossers, Tape Recorders, Scanners, Duxbury, Jaws Computer, Kurwzeil.

INTERVIEW RESULT: 3) Has your organization been deploying ICT in the transcription of reading materials into alternative formats. If yes, how long? If no, why?

Table 4. ICT in the transcription of reading materials

\begin{tabular}{|c|c|c|c|c|c|c|c|c|}
\hline $\begin{array}{l}\text { Gindiri Material } \\
\text { Centre for the Blind }\end{array}$ & $\begin{array}{l}\text { Anglo- Nigerian } \\
\text { Welfare Association } \\
\text { for the Blind Library }\end{array}$ & $\begin{array}{l}\text { Inlak Library for } \\
\text { the Visually } \\
\text { Handicapped }\end{array}$ & $\begin{array}{l}\text { Ikeja Farm Craft Centre } \\
\text { for the Blind }\end{array}$ & $\begin{array}{l}\text { Niger-Wives Braille } \\
\text { Production Centre }\end{array}$ & Pacelli School for the Blind & $\begin{array}{l}\text { Orji River } \\
\text { Rehabilitation } \\
\text { Centre for the } \\
\text { Blind }\end{array}$ & $\begin{array}{l}\text { Bola Ige } \\
\text { Information Centre }\end{array}$ & $\begin{array}{l}\text { Hope for } \\
\text { the Blind }\end{array}$ \\
\hline $\begin{array}{l}\text { "We started in } 2002 \\
\text { but stopped because of } \\
\text { broken down } \\
\text { equipment and lack of } \\
\text { money for repairs". }\end{array}$ & $\begin{array}{l}\text { Yes, since } 1999 . \text { We } \\
\text { engage in massive } \\
\text { production of } \\
\text { secondary and tertiary } \\
\text { books using IT } \\
\text { facilities". }\end{array}$ & $\begin{array}{l}\text { "We transcribe } \\
\text { students' handouts } \\
\text { from various } \\
\text { schools using } \\
\text { computer brailing } \\
\text { facilities". }\end{array}$ & $\begin{array}{l}\text { "Like I said earlier, we have } \\
\text { a Braille Center here in } \\
\text { Lagos that transcribes using } \\
\text { Perkins, } \\
\text { Embossers and some } \\
\text { computers. }\end{array}$ & $\begin{array}{l}\text { "We have been } \\
\text { deploying computers } \\
\text { and other assistive } \\
\text { technologies since } \\
2000 \text {. }\end{array}$ & $\begin{array}{l}\text { "They ask for Braille books more because } \\
\text { they can only read with their fingers and } \\
\text { not their eyes. I think the talking book is } \\
\text { more expensive because we have to get } \\
\text { the gadgets as we need to get the } \\
\text { Embossers also. So both of them have } \\
\text { their own problems which boil down to } \\
\text { funds". }\end{array}$ & $\begin{array}{l}\text { Yes but we depend } \\
\text { more on other } \\
\text { centres with better } \\
\text { computer brailing } \\
\text { facilities }\end{array}$ & Yes, since 2002 & Yes, 2008 \\
\hline
\end{tabular}

Source: Nkiko (2013). Copyright Exemption and Information Technology as Factors Influencing Transcription of Reading Materials into Alternative Format for the Visually Impaired in Nigeria, Unpublished Ph.D Thesis, University of Ibadan.

Table 4: revealed that majority of the institutions interviewed have been deploying ICT in the transcription of reading materials into alternative format.

INTERVIEW RESULT: 4) In what ways have ICT application impacted on transcription of reading materials to alternative format in Nigeria? 
Table 5. ICT in the transcription of reading materials

\begin{tabular}{|c|c|c|c|c|c|c|c|c|}
\hline Gindiri Material & Anglo- Nigerian & Inlak Library for the & Ikeja Farm Craft & Niger-Wives Braille & Pacelli School for & Orji River & Bola Ige & Hope for the Blind \\
\hline Centre for the & Welfare Association & Visually & Centre for the & Production Centre & the Blind & Rehabilitation & Information Centre & \\
\hline Blind & for the Blind Library & Handicapped & Blind & & & Centre for the Blind & & \\
\hline Makes Braille & It has enhanced reading & ICT has made possible & It has made & It has made Braille & It makes & The ease with which & People without prior & \\
\hline accessible and & and independence of the & the deployment or & possible the & searchable and & transcription & Braillist can make & knowledge of Braille & \\
\hline \multirow[t]{3}{*}{ portable } & blind students & read aloud books & existence of Braille & downloadable & faster with greater & multiple copies & can produce perfect & \\
\hline & & & Note- takers and & & precision and & & Brailled documents & \\
\hline & & & transcript software & & accuracy & & using technology & \\
\hline
\end{tabular}

Source: Nkiko (2013). Copyright Exemption and Information Technology as Factors Influencing Transcription of Reading Materials into Alternative Format for the Visually Impaired in Nigeria, Unpublished Ph.D Thesis, University of Ibadan.

Table 5 showed that respondents understood the positive impact of information technologies to transcription of reading materials. For the extent of application of Information Technology in the transcription of reading materials into alternative format, the interview revealed that transcribers know that information technology will make their work faster and easier. They understood how crucial computers and other relevant technology are to improving transcription of reading materials. Though many of the institutions still transcribe using conventional techniques, only few such as Inlak Library for the visually impaired. Nigerwives ANWAB claimed that information technology application has contributed immensely to the transcription of reading materials into alternative formats.

The interview also revealed that respondents are of the opinion that IT tools are expensive and spare-parts are not locally sourced. However, they affirmed that technological application to transcription represents most effective and global standards. It must be embraced if appreciable progress is to be made.

5) Do you have access to Jaws computer?

Table 6. ICT in the transcription of reading materials

\begin{tabular}{|c|c|c|c|c|c|c|c|c|}
\hline Gindiri Material & Anglo- Nigerian & Inlak Library for the & Ikeja Farm Craft & Niger-Wives & Pacelli School & Orji River & Bola Ige & Hope for \\
\hline Centre for the & Welfare Association for & Visually & Centre for the & Braille Production & for the Blind & Rehabilitation & Information & the Blind \\
\hline Blind & the Blind Library & Handicapped & Blind & Centre & & Centre for the Blind & Centre & \\
\hline Yes & Yes & Yes & No & Yes & No & No & Yes & Yes \\
\hline
\end{tabular}

6) Do you have formal training in the use of computer for transcription?

Table 7. ICT in the transcription of reading materials

\begin{tabular}{|c|c|c|c|c|c|c|c|c|}
\hline Gindiri Material & Anglo- Nigerian Welfare & Inlak Library for & Ikeja Farm & Niger-Wives Braille & Pacelli & Orji River & Bola Ige & Hope for \\
\hline Centre for the & Association for the Blind & the Visually & Craft Centre & Production Centre & School for & Rehabilitation & Information & the Blind \\
\hline Blind & Library & Handicapped & for the Blind & & the Blind & Centre for the Blind & Centre & \\
\hline \multirow[t]{3}{*}{$\begin{array}{l}\text { Yes, both local } \\
\text { and international }\end{array}$} & Yes, in our institution & Yes & No & Yes, formal training & No & No & Yes, of course & Yes \\
\hline & training are the norm for & & & are required & & & & \\
\hline & professional transcription & & & & & & & \\
\hline
\end{tabular}

Tables 6 and 7 showed respondents institutions access to Jaws Computers and availability of formal training in the use of computer for transcription. The preponderance of opinion is that they enjoy great deal of formal training as well as access to jaws computer.

There will be no significant relationship between information technology and transcription of reading materials into alternative format for the Visually Impaired in Nigeria. 


\section{Hypothesis}

Table 8. Correlation of application of information technology and transcription of reading materials into alternative formats for the Visually Impaired in Nigeria

\begin{tabular}{llllll}
\hline Variations & $\mathrm{N}$ & Mean & Std. Deviation & r-observed & Sig. \\
\hline $\begin{array}{l}\text { Application of Information Technology } \\
\begin{array}{l}\text { Transcription of reading materials into alternative } \\
\text { formats impaired }\end{array}\end{array}$ & 470 & 23.00 & 19.3851 & & $0.622^{* *}$ \\
\hline
\end{tabular}

** Correlation is significant at the 0.01 level (2-tailed).

The Table 8 represents correlation coefficient of independent variable (application of information technology) and dependent variable (transcription of reading materials into alternative formats for the Visually Impaired in Nigeria). The result revealed a significant positive relationship between application of information technology and transcription of reading materials into alternative formats for the visually impaired in Nigeria at $r=0.62: \mathrm{p}<0.05$. This implies that the null hypothesis that stated that "There will be no significant relationship between information technology and transcription of reading materials into alternative format for the visually impaired in Nigeria" is therefore rejected.

\section{Discussion}

The study indicated that there is a positive linear correlation between the application of IT and the transcription of reading materials into alternative format. The implication of this is that as the application of IT increases, the transcription of reading materials into alternative format for the visually impaired also increases in the same direction. This means that IT applications have significant influence on transcription of reading materials into alternative format for the visually impaired in Nigeria. Thus, the null hypothesis $\left(\mathrm{H}_{\mathrm{o}}\right)$ which states that information technology applications have no significant relationship with transcription of reading materials into alternative format for the visually impaired in Nigeria was rejected while the alternative hypothesis $\left(\mathrm{H}_{1}\right)$ was accepted. This finding is in agreement with Porter (1997), Gallimore (1999), Evans (2000), and Pollitt (2003) who separately noted the influence of information technology in the provision of reading materials in alternative formats for the visually impaired.

The study further showed that the various institutions for the visually impaired employ multifarious information technological tools in the transcription of reading materials but on the average there is low level of application of information technology in the transcription of reading materials for the visually impaired in Nigeria. However, Perkins Braille and Stylus which are traditional tools remained the predominant methods for transcription. Findings from the interviews corroborated this, with particular reference to Perkins Braille Machine, Embossers, Tape Recorders, Stylus and Scanners being the most widely used. These quotes from the respondents tend to capture these view points.

"The major tool among most transcribers is Perkin Braille and stylus, however, computer-based brailling is on the increase. They ask for the Braille books more because they can only read with their fingers and not their eyes. I think the talking book is more expensive because we have to get the gadget as we need to get the embosser also. So both of them have their own problems which boil down to funds" [Pacelli School for the Blind]. "We have a Braille center here in Lagos that transcribes, using Perkins, Embosser and some computers". [Farm craft]

The finding is consistent with Gusen et al. (2010) and Atinmo (2005) who asserted that transcription in Nigeria is mostly manual driven as only few institutions use computer Braille facilities. However, majority of the respondents are not satisfied with the present level of information technology application in the transcription of reading materials into alternative formats in Nigeria which could be attributed to poor funding, institutional priorities and low level of infrastructural and technological development of the country.

Respondents perceived the impact of information technology to transcription as laudable and of tremendous positive advantage. It was noted that it makes transcription faster with greater precision and accuracy as well as making possible the deployment of read aloud books among several other advantages. This positive perception and enthusiasm would definitely be a catalyst in the adoption and acceptance of relevant technologies to improve transcription in Nigeria. They are aware that they could still avail themselves of some other modern transcribing 
equipment such as AFB Product Evaluation, Assistive Vision Smart Glasses, Braille e-book reader and other sophisticated devices which are currently not available to them.

The finding is at variance with Evans (2000), Kuniansky (2001), Pollitt (2003), Nguyen (2005) and Verhoeven (2005) who noted that information technology is increasingly applied to the transcription of reading materials for the visually impaired. Print to Braille transcription using software can yield accuracy level that approaches $100 \%$. It is possible for a person who does not know Braille to produce decent, usable and useful Braille. This is particularly critical in educational settings, where students need Braille in a timely manner in order to keep current with their studies. Automatic transcription is an invaluable tool and resource, but it does not eliminate the need for skilled intervention from a knowledgeable person when quality Braille is the desired outcome.

\section{Conclusion and Recommendations}

The deployment of appropriate information technology is crucial for the transcription of reading materials into accessible formats for the visually impaired. The paper noted that the application of information technology in the transcription of reading materials into alternative formats is low. However, it indicated significant positive relationship of reading materials for the visually impaired. The study recommends that Multi-National Corporations should be sensitized to extend their Corporate Social Responsibility (CSR) activities to help in procuring modern information technology devices and software to enhance transcription. Stakeholders should improve upon their knowledge of information technology and other relevant issues through workshops, seminars and periodic formal training for personnel in order to be able to increase and sustain an adequate level of transcription activities in the institutions.

\section{References}

Apple, M. (1992). Is the New Technology part of the Solution or Part of the Problem in Education? In J. Beynon, \& H. Mackay (Eds.), Technological Literacy and the Curriculum (pp. 16-17). London: The Falmer.

Atinmo. (2000). Strategies and Tools for Library and Information Service Delivery for Visually Impaired Persons in Nigeria in the New Millennium. In Library and Agenda for the New Millennium. Nigeria Library Association.

Atinmo, M. I. (20005). Setting up a computerized catalogue and Distribution Database of Alternative Materials for Blind and Visually Impaired Person in Nigeria. Retrieved from http://www.foundation.v/verscroft.com/atinmo.htm. Accessed on 19/11/2008

Babalola, Y. T., \& Haliso, Y. (2011). Library and Information Services to the Visually Impaired-The Role of Academic Libraries. Canadian Social Science, 7(1), 140-147.

Banes, D. (2009). Braille 200 Years Old! Retrieved November 3, 2009, from http://telecentreeurope.ning.com/profiles/blogs/braille-200-years-old

Braille. (2000). Braille Production Technology for The New Millennium. Retrieved March 7, 2006, from http://www.braille 2000.com

COTIS. (2001). A Name Change, but the Ideals are the same. Retrieved August 13, 2006, from http://www.ukaaf.org/cotis-site/ontrack37.htm

Craddock, J. (1996). Talking Newspapers and Magazines for Visually Impaired and other People with Print Disabilities: An International Perspective. Paper presented at the $62^{\text {nd }}$ IFLA General Conference, 25-31 August. Retrieved December 11, 2005, from http://www.ifla/org/contacts.html

Craven, J. (2000). Good Design Principles for the Library Websites: A study of Accessibility Issues in UK University Libraries. New Review of Information and Library Research, 6, 25-51.

Disability Discrimination Act (DDA). (2005). Retrieved June 14, 2007, from http://www1.learningtrust.co.uk/adult_learning/adult_and_community_learning/docs/disability_discriminati on_act.pdf

Evans, M. (2000). Serving the needs of Visually Impaired Information Seekers in UK Public Libraries. In FLA Council and General Conference. Jerusalem: IFLA. Retrieved December 3, 2006, from http://www.ifla.org/iv/66/paper/111158E.html

Fuandai, C. (2010). Catering for children with special needs in the regular classroom: Challenges and the way forward. Edo Journal of Counselling, 3(1), 144-157.

Gallimore, A. (1999). When Special Becomes Everyday. Library Technology, 4(1), 13-16. 
Gusen, J. N. (1998). Information Technology (IT) as a Tool for Social and Economic Integration of Exceptional Children in Nigeria: Prospect and Problems. The Exceptional Child, 2(2), 45-49.

Amwe, D., \& Milaham. (2010). The use of technological implication. Retrieved from http://dspace.unijos.edu.ng/bitstream/10485/741/1/the use technological devices with blind chi/0001.pdf

Hill, J. L. (1990). Mainstreaming Visually Impaired Children: The Need for Modifications. Journal of Visually Impairment and Blindness, 84, 354-360.

Horten, G. K., \& Horten, E. K. (1995). Electronic Books for the Visually Impaired: The Norwegian Project. Retrieved from http://www.ifla.org/contacts/html

Kuniansky, N. (n.d.). E-braille: Making Braille Easy around the World. Retrieved from http://www.ifla.org/vii/331/anual/ivifla66/papers/027-158e.htm

Lang, R., \& Upah, L. (2008). Scoping study: Disability issues in Nigeria. Retrieved from http://www.ucl.ac.uk/lcccr/downloads/dfid_nigeriareport

Long, C. A. (1993). Making Information Available to Partially Sighted and Blind Clients. Electronic Library, 11(6), 373-384.

Nguyen, T. B. (2005). Services for the Blind in Public Libraries of Vietnam: Making Vietnamese Public Libraries more Accessible to Visually Impaired People. Retrieved from http://www.ifla71/papers/084exlguyen.pdf.htm

Nkiko, C. (2013). Copyright Exemption and Information Technology as Factors Influencing Transcription of Reading Materials into Alternative Format for the Visually Impaired In Nigeria. University of Ibadan.

Omede, A. (2011). Reforms in Special Education for Optimum Educational Attainment by persons with special Needs for National Sustainability. Journal of Emerging Trends in Educational Research and Policy Studies, 2(4), 296-300.

Pollit, C. (2003). Accessible OPACS. Retrieved from http://www.ifla.org/w/ifla71/papers/077-E.html

Porter, P. (1997). The reading washing machine. Vine, 106, 34-37.

Rendulic, D. I. (2011). Basic Concepts of Information and Communication Technology. Notes: Open Society for Idea Exchange Zagreb, Croatia. Retrieved from http://www.itdesk.info

Tiamiu, P. S. (2003). Access to Learning: Physically Disabled People. Retrieved from http://www.ashoka.org/fellows/viewprofile1.cfm?person/d=679

Vappu, T., \& Leanor, M. P. (1995). The Social Aspects of Telematics, Disabled and Elderly People and the Future Challenges. Telecommunications for all. Commission of European Communities, Information Industries and Innovation.

Verhoeven, P. (2005). Dolphin Launches the World's first access software on a portable pen. Retrieved from http://www.magnifiers.org/popularnews.php

\section{Copyrights}

Copyright for this article is retained by the author(s), with first publication rights granted to the journal.

This is an open-access article distributed under the terms and conditions of the Creative Commons Attribution license (http://creativecommons.org/licenses/by/4.0/). 